\title{
Nyssomyia intermedia (Lutz \& Neiva, 1912) and Nyssomyia neivai (Pinto, 1926) (Diptera: Psychodidae: Phlebotominae) geographical distribution and epidemiological importance
}

\author{
José Dilermando Andrade Filho/ ${ }^{+}$, Eunice A Bianchi Galati* , Alda Lima Falcão \\ Laboratório de Leishmanioses, Centro de Pesquisas René Rachou-Fiocruz, Av. Augusto de Lima 1715, 30190-002 Belo Horizonte, \\ MG, Brasil *Departamento de Epidemiologia, Faculdade de Saúde Pública, Universidade de São Paulo, São Paulo, SP, Brasil
}

Nyssomyia intermedia (Lutz \& Neiva 1912) and N. neivai (Pinto 1926) are possible vectors of tegumentary leishmaniasis in some regions of Brazil. Further, the latter was until recently, considered a junior synonym of the former. This study has the purpose of updating our knowledge of the geographical distribution of these species, based on specimens deposited at the collection of the Centro de Pesquisas René Rachou-Fiocruz, Faculdade de Saúde Pública-Universidade de São Paulo, and on data presented by literature as also to associate this distribution with the cutaneous leishmaniasis cases reported. It has been reported that $\mathrm{N}$. intermedia occurs in the states of the Northeastern Region, in Rio de Janeiro, Espirito Santo, on the northern coast of São Paulo, in eastern Minas Gerais, Mato Grosso do Sul, and Goiás, close to the border with Minas Gerais and Bahia. N. neivai occurs in the Southern Region, southern coast and in western São Paulo, southern and western Minas Gerais, southern Goiás, and southern Pará, beyond Argentina, Bolivia, and Paraguay. It is important to highlight that N. intermedia and N. neivai occur in sympatry in Minas Gerais and São Paulo. N. intermedia or N. neivai are predominant or are captured abundantly in several cutaneous leishmaniasis foci in the Southeastern and Southern regions of Brazil.

Key words: epidemiology - geographical distribution - Nyssomyia intermedia- Nyssomyia neivai - leishmaniasis - Phlebotominae

Knowledge of the sand fly's geographical distribution is fundamental to an understanding of features related to the transmission of some diseases, mainly leishmaniases, thus indicating areas at risk of acquiring infections. An accurate identification of sand fly species and of the leishmania vectors is therefore important.

Nyssomyia intermedia (Lutz \& Neiva 1912) and $N$. neivai (Pinto 1926) are captured in various parts of Brazil and show a remarkable intraspecific and intrapopulational variation gradient (Andrade Filho et al. 2006). They are morphologically close (Marcondes 1996, Andrade Filho et al. 2003), present great behavioral similarities, have been collected in both forests and anthropic environments, are anthropophilic, have already been found naturally infected with trypanosomatids, N. neivai (Forattini \& Santos 1952, Forattini et al. 1972, Casanova et al. 1995, Córdoba-Lanus et al. 2006) and $N$. intermedia (Aragão 1922, Rangel et al. 1984, Pita-Pereira et al. 2005), and are strongly suspected of being implicated in transmission of tegumentary leishmaniasis agents (Lainson \& Rangel 2003).

Financial support: Capes, Fiocruz

${ }^{+}$Corresponding author: jandrade@ cpqrr.fiocruz.br

Received 26 October 2006

Accepted 28 March 2007
Until recently, the two species were considered synonymous (Martins et al. 1978 Young \& Duncan 1994), However, Marcondes (1996) considered them as valid species, though he only succeeded indistinguishing the females. The morphological distinction of the males was presented by Andrade Filho et al. (2003).

The present work aims at updating on knowledge of the geographical distribution of $N$. intermedia and $N$. neivai, and at discussing their occurrence in cutaneous leishmaniasis endemic areas.

\section{MATERIALS AND METHODS}

Adult samples of $N$. intermedia and $N$. neivai from the collection of Centro de Pesquisas René RachouFiocruz and Faculdade de Saúde Pública-Universidade de São Paulo were examined in order to verify their geographical distribution. Besides these data, those given by Marcondes et al. (1998), who accurately identified some of the species involved, and also those more recently reported in the literature, were taken into consideration. These literatures had been cited in each locality where the species were identified.

The bibliographical reference for each county is presented between brackets after the county's name. When the distribution has been mentioned by another author or other authors and also in this present study, the reference is given and personal observations are added.

We have made an attempt to associate the occurrence of $N$. intermedia and/or $N$. neivai with the cutaneous leishmaniasis cases reported in the literature and also with reports sent in by the state health secretaries of Espírito Santo, Paraná, and Rio de Janeiro. 


\section{RESULTS}

A total of 4000 specimens, all previously identified as $N$. intermedia, were examined.

The geographical distribution of the two species is present below.

\section{Nyssomyia intermedia}

BRASIL: Piauí - Teresina (Marcondes et al. 1998), Ceará - Crato (JDAF's observations); Rio Grande do Norte - Coronel João Pessoa and Dr Severiano (Ximenes et al. 2000) Alagoas - Palmeira dos Índios (JDAF's observations). Pernambuco - Jaboatão dos Guararapes, Quipapá (JDAF's observations; Marcondes et al. 1998). Bahia - Barreiras, Ilhéus (Marcondes et al. 1998), Santo Amaro (Follador et al. 1999). Espírito Santo Afonso Cláudio (Ferreira et al. 2001), Aracruz, Colatina, Ecoporanga, Itaguaçu, Linhares, Mimoso do Sul, Santa Leolpoldina, Santa Tereza, Serra (Marcondes et al. 1998), Tancredinho (EABG's observations), Venda Nova do Imigrante (Marcondes et al. 1998), Viana (JDAF's observations; Marcondes et al. 1998), Vitória (JDAF's observations). Goiás - Sitio D'Abadia (JDAF's observation). Mato Grosso do Sul - Miranda (JDAF's observation). Minas Gerais - Aimorés, Além Paraíba (Marcondes et al. 1998, Brazil et al. 2006), Alto Caparaó (Saraiva et al. 2006), Araçuaí (Gontijo et al. 2002), Arinos, Barra Longa, Belo Horizonte, Bocaiúva, Buenópolis, Buritizeiro, Caeté, Caparaó (Saraiva et al. 2006), Caratinga, Cava Grande, Conceição de Ipanema, Conselheiro Pena, Coroací, Coronel Fabriciano, Curvelo, Corinto, Dom Cavati, Diamantina, Felipe dos Santos, Galiléia, Governador Valadares, Iapu, Itambacurí, Itanhomi, Januária, Juiz de Fora, Lagoa Santa (JDAF's observations, Marcondes et al. 1998), Lassance (JDAF's observations, Marcondes et al. 1998), Leolpoldina, Manhuaçu, Mantena, Mariana, Marliéria, Mutum, Pirapora, Pocrane, Pompeu (Marcondes et al. 1998), Porteirinha, Rio Casca, Santa Bárbara, São João do Paraíso, Silveirânea, Tarumirim, Timóteo (Andrade Filho et al. 1997), Viçosa (Santos de Marco et al. 2002), Volta Grande (JDAF's observations). Rio de Janeiro - Angra dos Reis (EABG's observation) Araruama, Cachoeiras de Macacu (Marcondes et al. 1998), Cardoso Moreira (Marcondes et al. 1998), Casimiro de Abreu (Souza et al. 2001), Cordeiro (Marcondes et al. 1998), Duque de Caxias, Ibicuí, Itaboraí, Itacurussa, Itaguaí (Marcondes et al. 1998), Itaperuna, Macaé, Magé, Muriqui, Niterói (JDAF's observations, Marcondes et al. 1998), Nova Iguaçu, Parati (Marcondes et al. 1998), Petrópolis (JDAF's observations, Souza et al. 2005), Rio Bonito (JDAF's observations, Marcondes et al. 1998), Rio de Janeiro, Silva Jardim (Souza et al. 2001), Teresópolis, Valença, Vassouras (JDAF's observations). São Paulo Bananal (Marcondes et al. 1998), Barra do Turvo (EABG's observations), Caraguatatuba (Marcondes et al. 1998), Eldorado (EABG'observations), Ilha Bela (EABG's observations), Iporanga (JDAF's observations, Galati et al. 2002), Itariri, Juquiá (EABG's observations), Pariqüera Açu (Marcondes et al. 1998), Pedro de Toledo (EABG's observations), São Sebastião (JDAF's observations, Marcondes et al. 1998, Brito et al. 2002), Taubaté (Casanova, unpublished data), Ubatuba (Marcondes et al. 1998).

\section{Nyssomyia neivai}

BRAZIL: Pará - São Geraldo do Araguaia (Galati, unpublished data). Goiás - Corumbaíba, Itumbiara (JDAF's observations, Marcondes et al. 1998). Mato Grosso do Sul - Bataguassu (EABG's observations). Minas Gerais - Alfenas, Arinos, Bambuí (JDAF's observations, Marcondes et al. 1998), Betim, Conceição do Rio Verde, Coração de Jesus, Corinto, Divinópolis, Esmeralda, João Pinheiro (Marcondes et al. 1998), Lagoa Santa, Lassance, Paracatu, Passos, Pedro Leolpoldo, Perdões (JDAF's observations, Marcondes et al. 1998), Pirapora, Presidente Olegário, Tupaciguara, Uberlândia (JDAF's observations). São Paulo - Angatuba, Araçatuba, Araraquara, Atibaia (Marcondes et al. 1998), Barra do Turvo, Barueri, Caçapava (EABG's observations), Cajamar (Marcondes et al. 1998), Cajati (EABG's observation), Capela do Alto (Marcondes et al. 1998), Conchal (Casanova et al. 2005), Dourado, Eldorado (Marcondes et al. 1998, EABG's observations), Iporanga (Marcondes et al. 1998, Galati et al. 2002), Itariri (EABG's observations), Itupeva (Marcondes et al. 1998), Juquiá, Luis Antônio (EABG's observations), Miracatu, Monte, Natividade da Serra (Marcondes et al. 1998), Osasco, Ourinhos (EABG's observations), Pariqüera Açu, Pedro de Toledo, Pereira Barreto, Pirapora do Bom Jesus, Porto Ferreira (Marcondes et al. 1998), Ribeirão Branco (EABG's observations), São José dos Campos (EABG's observations), São Luís do Paraitinga (Marcondes et al. 1998), São Paulo (JDAF's observations, Marcondes et al. 1998), São Roque (Marcondes et al. 1998), Taubaté (Casanova, unpublished data), Teodoro Sampaio (Marcondes et al. 1998). Paraná Bandeirantes (Massafera et al. 2005), Cianorte, Fênix, Jussara, Paiçandu, Peroba (Marcondes et al. 1998), Ribeirão Claro (EABG's observations), Santo Antônio, São Jorge do Ivaí (Marcondes et al. 1998), Terra Boa (Teodoro et al. 2001). Santa Catarina - Biguaçu, Indaial, Itajaí, Quilombo (JDAF's observations, Marcondes et al. 1998), Rancho Queimado (Marcondes et al. 1998), Santo Amaro da Imperatriz, São Carlos (JDAF's observations). Rio Grande do Sul - Campo Novo (Marcondes et al. 1998), Porto Alegre (EABG's observations), Santa Maria (Marcondes et al. 1998), Tenente Portela (JDAF's observations, Silva \& Grunewald 1999). ARGENTINA: Corrientes (Salomón et al. 2006a), Entre Rios (Salomón et al. 2006b), Formosa (Salomón et al. 2002), Salta (Salomón et al. 2004), Santa Fé (Salomón et al. 2006b), Tucumán (Marcondes et al. 1998, Córdoba-Lanus \& Salomón 2002, Córdoba-Lanus et al. 2006). BOLIVIA: Tarija (Marcondes et al. 1998). PARAGUAY: Alto Paraná (Marcondes et al. 1998), Itapua and Misiones (Salomón et al. 2003).

\section{DISCUSSION}

The data on geographical distribution reported by Marcondes et al. (1998) are similar to those found in this present study, which corroborates the validity and possibility of accurately identifying both species.

The geographical distribution of $N$. intermedia s. $l$. is very wide, occurring in Argentina, Bolivia, Paraguay, and in all Brazilian regions, in Northern, Northeastern, 
and Mid-Western states, however, they are not as abundant as in the Southeastern and Southern states.

In the Northern Region, $N$. neivai may be limited to southern of Pará where it has been captured in São Geraldo do Araguaia, on the Serra das Andorinhas (Galati, unpublished data). In Tocantins, neither of the two species was captured (Andrade Filho et al. 2001), nevertheless, Carvalho et al. (1989) mentioned the presence of $N$. intermedia in other areas. However, accurate identification of this taxon is necessary, having in mind that this area may be a dispersion corridor for $N$. neivai from the Southern Region, western São Paulo and the Triângulo Mineiro as far as the state of Pará.

In the Mid-Western Region, both species were found. In Goiás, $N$. intermedia has been reported in Sítio D'Abadia county and N. neivai in Corumbaíba and Itumbiara. Its presence in this latter county has also been reported by Marcondes et al. (1998). The presence of $N$. neivai and $N$. intermedia is also confirmed In the state of Mato Grosso do Sul, the former in Bataguassu and the second in Miranda counties; both species however seem to be rare in this state, as no other authors have reported it (Galati et al. 1996, 2006 Oliveira et al. 2003), as well as in the state of Mato Grosso (Biancardi \& Bermudéz 2000, Azevedo et al. 2002).

Only $N$. intermedia has been reported in the Northeastern Region. In Piauí, it have reported in Teresina and in the state of Ceara this species has occurred only in Crato county. In the state of Rio Grande do Norte, Ximenes et al. (2000) report it in two municipalities but no specimen has been examined in the present study. In the state of Paraíba, this species has already reported (Martins et al. 1978), however no specimen has been examined in this study and Marcondes et al. (1998) considered it to be $N$. intermedia s.l. In Pernambuco, has been possible to confirm the presence of $N$. intermedia in two counties. In this latter state, however, its frequency is also very low. In Alagoas $N$. intermedia was captured in July 1999 in Palmeira dos Índios county, and it corresponded to about $10 \%$ of all the insects captured (JDAF's observation). In Sergipe, Marcondes et al. (1998) reported $N$. intermedia s.l., though no specimen from this state has been examined in.

In Bahia, N. intermedia presented a wider distribution; however, its frequency is low in the majority of the counties (Vexenat et al. 1986, Sherlock et al. 1996), except in Santo Amaro and "Fazenda Vovo" (Follador et al. 1999, Pereira \& Hoch 1990), where this species was prevalent, thus differing from the general tegumentary leishmaniasis pattern, in other areas of the state where Nyssomyia whitmani (Antunes \& Coutinho 1939) is the main vector species (Vasconcelos et al. 1994, Azevedo et al. 1996). Pereira and Hoch (1990) do not reported in which county the "Fazenda Vovo" is located.

In the Southeastern Region, both species occur in Minas Gerais and São Paulo as previously reported by Marcondes et al. (1998). In Rio de Janeiro and Espírito Santo, only $N$. intermedia has been found.

In Espírito Santo, $N$. intermedia is quite abundant and is suspected of transmitting leishmaniases in some re- gions of the state (Falcão et al. 1991). In Afonso Cláudio county, this species occurs with higher frequency in regions below $750 \mathrm{~m}$ a.s.l. It is at these altitudes that the highest indices of tegumentary leishmaniasis cases are found (Ferreira et al. 2001). This state is composed of 77 counties, in 13 of which the presence of $N$. intermedia has been reported. It was in those 13 counties that $43 \%$ of all the cases of tegumentary leishmaniasis in the state notified from 1986 to 1996 occurred. This figure attained $46 \%$ in 1997 ; with a gradual fall to $25 \%$ by the first semester of 2002 (Fundação Nacional de Saúde and Secretaria do Estado da Saúde do Espírito Santo).

In Rio de Janeiro, $N$. intermedia is very frequent in several regions, being the predominant species in several areas (Rangel et al. 1990, Brazil et al. 1991, Oliveira et al. 1995). Aguiar et al. (1987) found a large number of specimens of this species in Itaguaí, being most frequently captured biting humans. In Petrópolis county, this species predominated on the human bait $(80.3 \%)$, has been collected in larger numbers in the hottest months of the year (Souza et al. 2002) and presented significant positive correlations with the intensity of the moonlight when captured with human bait and negative one with CDC light traps (Souza et al. 2005). In this state, though it has been possible to confirm the presence of $N$. intermedia in 25 of the 82 counties, in four of them (Cardoso Moreira, Ibicuí, Itacurussa, and Muriqui) no tegumentary leishmaniasis have been reported. In the state of Rio de Janeiro, 4212 cases of this disease were registered between 1985 and 2001; 57\% of these cases occurred in those counties in which $N$. intermedia has been identified (Secretaria de Estado de Saúde do Rio de Janeiro).

In Minas Gerais, the distribution of $N$. intermedia and $N$. neivai basically follows that reported by Marcondes et al. (1998). N. intermedia occurs in the following regions: Jequitinhonha, Vale do Rio Doce, Metallurgic, and Zona da Mata, whereas $N$. neivai occurs in the Triângulo Mineiro and southern region. Both are found in Alto São Francisco and the northeast regions.

Both species are found sympatrically in Arinos, Pirapora, Lassance, and Corinto counties and with the exception of the first, where only one specimen of $N$. intermedia and two of $N$. neivai were analyzed, a high predominance was observed for one or the other. Interestingly, all these counties lie along large rivers (Urucaia river in Arinos, São Francisco river in Pirapora, and Velhas river in Lassance and Corinto), which may be serving as geographical barriers to separate the two species, and the few specimens of one or other species that could reach the opposite bank are not numerous enough to compete with the prevailing species. It is important, however, to carry out systematized captures in these counties in order to corroborate this point of view, since the captures were carried out on the left bank of the Velhas river in Lassance and Corinto, and it was not possible to carry them out on the other bank to verify if there was any difference in the species composition and predominance.

In Lagoa Santa, in the metropolitan region of Belo Horizonte, both species seem to have occurred; they were collected with low frequency in Lapinha's cave, though in different periods between 1957 and 1960. From 1993 
to 1995 , only $N$. intermedia was collected in this cave (Andrade Filho et al. 1998).

In other counties of the metropolitan region of Belo Horizonte, both species have been observed, N. intermedia in the capital and N. neivai in Betim, Esmeraldas, and Pedro Leopoldo.

$N$. intermedia seems to be the tegumentary leishmaniasis vector in several areas of Minas Gerais, such as Araçuaí, where, in a survey of an outbreak of this disease, $99 \%$ of the sand flies collected were of this species (Gontijo et al. 2002). A similar result has been reported in Alto Caparaó and Caparaó, where it is also implicated as the likely vector (Saraiva et al. 2006).

In Corinto, it was possible to investigate some human cases of the disease, and N. neivai is thought to be the vector, as it represented about $90 \%$ of all sand flies captured, there being frequent inside homes, causing bothersome to the inhabitants as the insects bite frequently inside residences.

In São Paulo, both species were found to be sympatric in the region of the Vale do Ribeira, in Pariquiera Açu (Marcondes et al. 1998), Iporanga (Galati et al. 2002), Barra do Turvo, Eldorado, Itariri, Juquiá, and Pedro de Toledo (EABG's observations), as also in Taubaté county, in the Paraíba Valley (Casanova, unpublished data). In the present study, $N$. intermedia was captured on the northern coastline of the state and N. neivai, in the countryside, which is in accordance with Marcondes et al. (1998). The deforestation of the area previously covered with Atlantic forest seems to be benefiting $N$. intermedia s.l. to the detriment of other species such as $N$. whitmani and Pintomyia pessoai (Coutinho \& Barretto 1940, Gomes et al. 1989, 1995).

On the northern coastline of São Paulo, $N$. intermedia was the most abundant species accounting for virtually $95 \%$ of the total sand flies captured in the intradomicile, peridomicile, and the woods (Brito et al. 2002). On the southern coastline, in Cananéia county, $N$. intermedia s.l. occurs infrequently whether in the woods or in the domicile, whereas in Iguape county, it was the only taxon reported (Gomes \& Galati 1989, Gomes et al. 1990).

In the Ribeira Valley, an endemic area for tegumentary leishmaniasis, in Pariqüera Açu county, $N$. intermedia s.l. seems to be more adapted to the modified environment, being considered a tegumentary leishmaniasis vector (Gomes et al. 1980), with the vector-human contact occurring in the domicile (Gomes et al. 1983). This taxon still prevails in residual woodland, on the border of the woods and on open land (Gomes \& Galati 1987). In the county of Pedro de Toledo, $N$. intermedia s.l. prevailed, mainly in intra and peridomicile (Domingos et al. 1998).

In the mid-western of São Paulo, in Araraquara and São João da Boa Vista counties, a few specimens of $N$. intermedia s.l. were captured in the woods, whereas in two other counties with larger prevalence of this species, Dourado and Mogi-Guaçu, the inverse occurred, though this woods there were not so well conserved as in the former (Gomes et al. 1989). This taxon also prevailed in the western São Paulo, in the county of Teodoro
Sampaio (Condino et al. 1998). According to the distribution reported by Marcondes et al. (1998), N. neivai is likely to prevail in these counties.

In São Paulo, a correlation of $88 \%$ was found in the counties investigated between the presence of cases of tegumentary leishmaniasis and the presence of $N$. intermedia s.l., being this taxon the most frequent among the species colleted, with the widest distribution and prevailing, together with Migonemyia migonei (França, 1920) in all kinds of vegetation and in all topographical regions; both being considered the principal vectors (Camargo-Neves et al. 2002).

In Paraná, $N$. neivai occurs in the greater part of the state (Marcondes et al. 1998), there being no report of $N$. intermedia, though it may occur in the northeastern region close to the border with São Paulo, where $N$. intermedia has been reported. Jussara county, where $N$. neivai (mentioned as $N$. intermedia) prevailed (Aguiar et al. 1989), presented an incidence of 422.80 cases of tegumentary leishmaniasis per 100,000 inhabitants in 2000, the highest incidence in Paraná (data from "Secretaria Estadual de Saúde").

In Santa Catarina and Rio Grande do Sul, only the occurrence of N. neivai was reported (Marcondes et al. 1998), it being widely prevalent in Santa Catarina, mainly in modified areas. In Rio Grande do Sul, as few studies have been carried out, its prevalence has been reported only in the "Parque Estadual do Turvo", in Tenente Portela county (Dias et al. 1997) and Derrubadas county (Silva et al. 2004).

According to these data, $N$. intermedia or $N$. neivai prevail or are abundant in several Brazilian areas and $N$. neivai in Paraguayan and Argentinean areas in which tegumentary leishmaniasis occurs. According to KillickKendrick (1988), in order to confirm the disease-vector species, it is important to meet the following criteria: (1) the species should be abundant in the leishmaniasis focus; (2) it should be highly anthropophilic; (3) it should present the development of the parasite in the absence of blood in the gut; (4) it should show the highest natural infection rate among the sand flies observed; and (5) the parasites isolated from sand flies should be indistinguishable from those isolated from human cases.

$N$. intermedia and $N$. neivai presented characteristics that meet the first and second criteria above. As for the third and fourth criteria, several studies have already shown natural infection among sand flies of these two species, with natural infection by flagellates indices, varying from 0.1 - at least $0.85 \%$ (Forattini \& Santos 1952, Forattini et al. 1972, Rangel et al. 1984, Casanova et al. 1995, PitaPereira et al. 2005, Cordoba-Lanus et al. 2006). Only the last criterion for these species has not been met, as date, sand fly parasites have not been isolated, characterized or compared with those obtained from human patients.

Experiments have shown that these species may be easily infected with several strains and species of Leishmania (Chagas 1940, Coelho et al. 1967, Rangel et al. 1992, 1993, Silva \& Gomes 2001), which shows that these species are susceptible to infection by Leishmania. In the light of these data, there seems to be little doubt as to the vectorial capacity of $N$. intermedia and $N$. neivai. 


\section{REFERENCES}

Aguiar GM, Vilela ML, Ferreira VA, Santos TG 1989. Ecologia dos flebótomos em recente foco ativo de leishmaniose tegumentar no norte do estado do Paraná (Diptera, Psychodidae, Phlebotominae). Mem Inst Oswaldo Cruz 84: 7-8.

Aguiar GM, Vilela ML, Lima RB 1987. Ecology of the sand flies of Itaguaí, an area of cutaneous leishmaniasis in the state of Rio de Janeiro. Food preferences (Diptera, Psychodidae, Phlebotominae). Mem Inst Oswaldo Cruz 82: 583-584.

Andrade Filho JD, Carneiro APS, Lima MLN, Santiago RM, Gama MA, Santos CA, Falcão AL, Brazil RP 1997. Flebotomíneos de Timóteo, estado de Minas Gerais, Brasil (Diptera: Psychodidae). Cad Saú Públ 13: 767-770.

Andrade Filho JD, Galati EAB, Falcão AL 2003. Redescription of Nyssomyia intermedia (Lutz \& Neiva, 1912) and Nyssomyia neivai (Pinto, 1926) (Diptera: Psychodidae). Mem Inst Oswaldo Cruz, 98: 1059-1065.

Andrade Filho JD, Galati EAB, Falcão AL 2006. Polymorphism, inter-population and inter-specific variation in Nyssomyia intermedia (Lutz \& Neiva) and Nyssomyia neivai (Pinto) (Diptera, Psychodidae, Phlebotominae). Rev Bras Entomol 50:385-393.

Andrade Filho JD, Lima MLN, Falcão AL, Brazil RP 1998. Sazonalidade dos flebotomíneos (Diptera, Psychodidae) dos arredores da Gruta da Lapinha, município de Lagoa Santa, Minas Gerais, Brasil. Rev Bras Ent 42: 93-95.

Andrade Filho JD, Valente MB, Andrade WA, Brazil RP, Falcão AL 2001. Flebotomíneos do Estado de Tocantins, Brasil (Diptera: Psychodidae). Rev Soc Bras Med Trop 34: 323-329.

Aragão HB 1922. Transmissão de leishmaniose no Brasil pelo Phlebotomus intermedius. Bras Med 36: 129-130.

Azevedo ACR, Souza NA, Meneses CRV, Costa WA, Costa SM, Lima JB, Rangel EF 2002. Ecology of sand flies (Diptera: Psychodidae: Phlebotominae) in the north of the state of Mato Grosso, Brazil. Mem Inst Oswaldo Cruz 97: 459-464.

Azevedo ACR, Vilela ML, Souza NA, Andrade-Coelho CA, Barbosa AF, Firmo ALS, Rangel EF 1996. The sand fly fauna (Diptera: Psychodidae: Phlebotominae) of a focus of cutaneous leishmaniasis in Ilhéus, state of Bahia, Brazil. Mem Inst Oswaldo Cruz 91: 75-79.

Biancardi CMB, Bermúdez EG 2000. Flebotomíneos (Diptera: Psychodidae) no Estado do Mato Grosso, Município de Chapada dos Guimarães, Brasil. Act Amaz 30: 115-128.

Brazil RP, Almeida DC, Brazil BG, Oliveira Mamede SM 1991. Chicken house as a resting site of sand flies in Rio de Janeiro, Brazil. Parassitologia 33 (Suppl.): 113-114.

Brazil RP, Passos WL, Fuzari AA, Falcão AL, Andrade Filho JD 2006. The peridomiciliar sand fly fauna (Diptera: Psychodidae) in areas of cutaneous leishmaniasis in Além Paraíba, Minas Gerais, Brazil. J Vector Ecol 31: 418-420.

Brito M, Casanova C, Mascarini LM, Wanderley DMV, Corrêa FMA 2002. Phlebotominae (Diptera: Psychodidae) em área de transmissão de leishmaniose tegumentar americana no litoral norte do Estado de São Paulo, Brasil. Rev Soc Bras Med Trop 35: 431-437.

Camargo Neves VLF, Gomes AC, Antunes JLF 2002. Correlação da presença de espécies de flebotomíneos (Diptera: Psychodidae) com registros de casos da leishmaniose tegumentar americana no Estado de São Paulo, Brasil. Rev Soc Bras Med Trop 35: 299-306.

Carvalho MES, Lustosa ES, Naves HAM 1989. Contribuição ao conhecimento da fauna flebotomínica no Estado de Goiás e Distrito Federal. II. 1986-1987. Rev Pat Trop 18: 7-14.

Casanova C, Costa AIP, Natal D 2005. Dispersal pattern of the sand fly Lutzomyia neivai (Diptera: Psychodidae) in a cutaneous leishmaniasis endemic rural area in Southeastern Brazil. Mem Inst Oswaldo Cruz 100: 719-724.

Casanova C, Mayo RC, Rangel O, Mascarini LM, Pignatti MG, Galati EAB, Gomes AC 1995. Natural Lutzomyia intermedia (Lutz \& Neiva) infection in the Valley of the Mogi Guaçú River, State of São Paulo, Brazil. Bol Dir Malariol San. Amb 35 (Supl. 1): 77-84.

Chagas AW 1940. Criação de flebótomos e criação experimental da leishmaniose visceral americana. Mem Inst Oswaldo Cruz 35: 327-333.

Coelho MV, Falcão AR, Falcão AL 1967. Desenvolvimento de espécies do gênero Leishmania em espécies brasileiras do gênero Lutzomyia França, 1924. I - Evolução de L. braziliensis em flebótomos. Rev Inst Med Trop São Paulo 9: 177-191.

Condino MLF, Sampaio SMP, Henriques LF, Galati EAB, Wanderley DMV, Corrêa FMA 1998. Leishmaniose tegumentar americana: flebotomíneos de área de transmissão no município de Teodoro Sampaio, região sudoeste do estado de São Paulo, Brasil. Rev Soc Bras Med Trop 31: 355-360.

Cordoba-Lanus E, Salomón OD 2002. Phlebotomine fauna in the province of Tucumán, Argentina. Rev Inst Med Trop São Paulo 44: 23-27.

Cordoba-Lanus E, De Grosso ML, Pinero JE, Valladares B, Salomón OD 2006. Natural infection of Lutzomyia neivai with Leishmania spp. in northwestwern Argentina. Acta Trop 98: 1-5.

Dias ES, Falcão AL, Silva JE 1997. Notes on the sand fly (Diptera: Psychodidae) in the state of Rio Grande do Sul, Brazil. Mem Inst Oswaldo Cruz 92: 329-332.

Domingos MF, Carreri-Bruno GC, Ciaravolo RMC, Galati EAB, Wanderley DMV, Corrêa FMA 1998. Leishmaniose tegumentar americana: flebotomíneos de área de transmissão, no município de Pedro de Toledo, região sul do estado de São Paulo, Brasil. Rev Soc Bras Med Trop 31: 425-432.

Falcão AL, Falcão AR, Pinto CT, Gontijo CM, Falqueto A 1991. Effect of deltamethrin spraying on the sand fly populations in a focus of American cutaneous leishmaniasis. Mem Inst Oswaldo Cruz 86: 399-404.

Ferreira AL, Sessa PA, Varejão JBM, Falqueto A 2001. Distribution of sand flies (Diptera: Psychodidae) at different altitudes in an endemic region of American cutaneous leishmaniasis in the state of Espírito Santo, Brazil. Mem Inst Oswaldo Cruz. 96: 1061-1067.

Follador I, Araujo C, Cardoso MA, Tavares-Neto J, Barral A, Miranda JC, Bittencourt A, Carvalho EM 1999. Surto de leishmaniose tegumentar americana em Canoa, Santo Amaro, Bahia, Brasil. Rev Soc Bras Med Trop 32: 497-503.

Forattini OP, Santos MR 1952. Nota sobre infecção natural de Phlebotomus intermedius Lutz \& Neiva, 1912, por formas leptomonas, em um foco ativo de leishmaniose tegumentar americana. Arq Hig S Paulo 17: 171-174. 
Forattini OP, Pattoli DBG, Rebello EX, Ferreira AO 1972. Infecção natural de flebotomíneos em foco enzoótico de leishmaniose no estado de São Paulo, Brasil. Rev Saú Públ 6: 431-433.

Galati EAB, Marassá AM, Andrade RMG, Pinto PLS, Consales CA, Karmann I, Bueno EFM 2002. Phlebotomines from speleological province of Ribeira Valley, São Paulo State, Brasil. Entomol Vect (Suppl. 1): 38-39.

Galati EAB, Nunes VLB, Bogiani PC, Dorval MEC, Cristaldo G, Rocha HC, Oshiro ET, Damasceno Júnior GA 2006. Phlebotomines (Diptera: Psychodidae) in forested areas of the Serra da Bodoquena, state of Mato Grosso do Sul, Brazil. Mem Inst Oswaldo Cruz 101: 175-192.

Galati EAB, Nunes VLB, Dorval MEC, Oshiro ET, Cristaldo G, Espíndola MA, Rocha HC, Garcia WB 1996. Estudo dos flebotomíneos (Diptera, Psychodidae), em área de leishmaniose tegumentar, no Estado de Mato Grosso do Sul, Brasil. Rev Saú Públ 30: 115-128.

Gomes AC, Galati EAB 1987. Aspectos ecológicos da leishmaniose tegumentar americana. 5. Estratificação da atividade especial e estacional de Phlebotominae (Diptera, Psychodidae) em áreas de cultura agrícolas da região do Vale do Ribeira, estado de São Paulo, Brasil. Mem Inst Oswaldo Cruz 82: 467-473.

Gomes AC, Galati EAB 1989. Aspectos ecológicos da leishmaniose tegumentar americana. 7. Capacidade vetorial flebotomínea em ambiente florestal primário do sistema da Serra do Mar, região do Vale do Ribeira, estado de São Paulo, Brasil. Rev Saú Públ 23: 136-142.

Gomes AC, Barata JMS, Rocha e Silva EO, Galati EAB 1989. Aspectos ecológicos da leishmaniose tegumentar americana. 6. Fauna flebotomínea antropofílica de matas residuais situadas na região centro-nordeste do estado de São Paulo. Rev Inst Med Trop São Paulo 31: 32-39.

Gomes AC, Galati EAB, Casanova C, Domingos MF, Marques GRAM, Neves VLF 1995. Analysis of the geographical distribution of leishmaniasis vectors in the state of São Paulo Brazil. Bol Dir Malariol San Amb 35 (Supl. 1): 143-146.

Gomes AC, Galati EAB, Glasser CM 1990. Nota sobre o encontro de Phlebotominae (Diptera: Psychodidae) no litoral sul do estado de São Paulo, Brasil. Rev Saú Públ 24: 319-320.

Gomes AC, Rabello EX, Santos JLF, Galati EAB 1980. Estudo experimental da freqüência de flebotomíneos a ecótopos artificiais com referência especial a Psychodopygus intermedius. Rev Saú Públ 14: 540-556.

Gomes AC, Rabello EX, Santos JLF, Galati EAB 1983. Aspectos ecológicos da leishmaniose tegumentar americana. 3. Observações naturais sobre o ritmo diário da atividade de Psychodopygus intermedius em ambiente florestal e extraflorestal. Rev Saúde Pública 17: 23-30.

Gontijo CMF, Silva ES, Fuccio MB, Sousa MCA, Pacheco RS, Dias ES, Andrade Filho JD, Brazil RP, Melo MN 2002. Epidemiological studies of an outbreak of cutaneous leishmaniasis in the Rio Jequitinhonha Valley, Minas Gerais, Brazil. Acta Trop 81: 143-150.

Killick-Kendrick R 1988. Studies and criteria for the incrimination of vector and reservoir hosts of the leishmaniasis. In Proceeding of the International Workshop on Control Strategies for the leishmaniasis. Ottawa: International Development Research Center, p. 272-280.
Lainson R, Rangel EF 2003. Ecologia das leishmanioses: transmissores de leishmaniose tegumentar americana. In EF Rangel, R Lainson (eds), Flebotomíneos do Brasil, Fiocruz, Rio de Janeiro, p. 291-309.

Marcondes CB 1996. A redescription of Lutzomyia (Nyssomyia) intermedia (Lutz \& Neiva, 1912), and resurrection of $L$. neivai (Pinto, 1926) (Diptera, Psychodidae, Phlebotominae). Mem Inst Oswaldo Cruz 91: 457-462.

Marcondes CB, Lozovei AL, Vilela JH 1998. Distribuição geográfica de flebotomíneos do complexo Lutzomyia intermedia (Lutz \& Neiva, 1912) (Diptera, Psychodidae). Rev Soc Bras Med Trop 31: 51-58.

Martins AV, Williams P, Falcão AL 1978. American Sand flies (Diptera: Psychodidae: Phlebotominae), Acad Bras Ciências, Rio de Janeiro, 195 pp.

Massafera R, Silva AL, Carvalho AP, Santos DR, Galati EAB, Teodoro U 2005. Fauna de flebotomíneos do município de Bandeirantes, no Estado do Paraná. Rev Saúde Pública 39: 571-577.

Oliveira AG, Andrade Filho JD, Falcão AL, Brazil RP2003. Estudo de flebotomíneos (Diptera: Psychodidae) na zona urbana da cidade de Campo Grande, Mato Grosso do Sul, Brasil, 19992000. Cad Saú Públ 19: 933-944.

Oliveira SMP, Afonso RCH, Dias CMG, Brazil RP 1995. Estudo da fauna de flebotomíneos (Diptera: Psychodidae) em Santa Cruz, município do Rio de Janeiro, Brasil. Rev Brasil Entomol 39: 547-551.

Pereira IR, Hoch A 1990. Lutzomyia intermedia as a suspected vector of Leishmania (Viannia) braziliensis in Bahia State, Brazil. Rev Soc Bras Med Trop 23: 235.

Pita-Pereira D, Alves CR, Souza MB, Brazil RP, Bertho AL, Barbosa AF, Britto CC 2005. Identifications of naturally infected Lutzomyia intermedia and Lutzomyia migonei with Leishmania (Viannia) braziliensis in Rio de Janeiro (Brazil) revealed by a PCR multiplex non-isotopic hybridization assay. Acta Trop 99: 905-913.

Rangel EF, Azevedo ACR, Andrade CA, Souza NA, Wermelinger ED 1990. Studies on sand fly fauna (Diptera: Psychodidae) in a focus of cutaneous leishmaniasis in Mesquita, Rio de Janeiro state, Brazil. Mem Inst Oswaldo Cruz 85: 39-45.

Rangel EF, Barbosa AF, Andrade CA, Souza NA, Wermelinger ED 1992. Development of Leishmania (Viannia) braziliensis Vianna, 1911 in Lutzomyia intermedia (Lutz \& Neiva, 1912) (Diptera: Psychodidae: Phlebotominae) under experimental conditions. Mem Inst Oswaldo Cruz 87: 235-238.

Rangel EF, Souza NA, Wermelinger ED, Barbosa AF 1984. Infecção natural de Lutzomyia intermedia Lutz \& Neiva, 1912 em área endêmica de leishmaniose tegumentar no estado do Rio de Janeiro. Mem Inst Oswaldo Cruz 79: 395-396.

Rangel EF, Travi BL, Barosa AF, Montoya J 1993. Development of Colombian isolates of Leishmania (Viannia) panamensis, Le $(V$.$) guyanensis, and Le (V$.$) braziliensis in the sand fly$ Lutzomyia intermedia (Lutz \& Neiva, 1912) under experimental conditions. Mem Inst Oswaldo Cruz 88: 313-315.

Salomón OD, Mocarbel NJ, Pedroni E, Colombo J, Sandillu M 2006b. Phlebotominae vectors of leishmaniasis in the provinces of Santa Fe and Entre Rios, Argentina. Medicina 66: 220-224. 
Salomón OD, Rossi GC, Cousiño B, Spinelli GR, Rojas de Arias A, López del Puerto DG Ortiz AJ 2003. Phlebotominae sand flies in Paraguay. Abundance distribution in the Southeastern region. Mem Inst Oswaldo Cruz 98: 185-190.

Salomón OD, Sosa-Estani S, Lucia DRI, Donnet M, Galarza R, Recalde H, Tijera A 2002. Leishmaniosis tegumentaria en las lomitas, provincia de Formosa, Argentina 1992-2001. Medicina 62: 562-568.

Salomón OD, Sosa-Estani S, Ramos K, Wenceslao-Ovellano P, Sanguesa G, Fernández G, Sinagra A, Rapasciolli G 2006a. Tegumentary leishmaniasis outbreak in Bella Vista city, Corrientes, Argentina, during 2003. Mem Inst Oswaldo Cruz 101: 767-774.

Salomón OD, Wilson ML, Munstermann LE, Travi BL 2004. Spatial and temporal patterns of phlebotomine sand flies (Diptera: Psychodidae) in a cutaneous leishmaniasis focus in northern Argentina. J Med Entomol 41: 33-39.

Santos de Marco T, Gaia MCM, Brazil RP 2002. Influence of the lunar cycle on the activity of phlebotomine sand flies (Diptera: Psychodidae). J Am Mosq Control Assoc 18: 114-118.

Saraiva L, Lopes JS, Oliveira GBM, Batista FA, Falcão AL, Andrade Filho JD 2006. Estudo dos flebotomíneos (Diptera: Psychodidae) em área de leishmaniose tegumentar americana nos municípios de Alto Caparaó e Caparaó, Estado de Minas Gerais, Brasil. Rev Soc Bras Med Trop 39: 56-63.

Sherlock IA, Maia H, Dias-Lima AG 1996. Resultados preliminares de um projeto sobre a ecologia dos flebotomíneos vetores de leishmaniose tegumentar no Estado da Bahia. Rev Soc Bras Med Trop 29: 207-214.

Silva AC, Gomes AC 2001. Estudo da Competência vetorial de Lutzomyia intermedia (Lutz \& Neiva, 1912) para Leishmania (Viannia) braziliensis, Vianna, 1911. Rev Soc Bras Med Trop 34: 187-191.

Silva OS, Grunewald J 1999. Contribution to the sand fly fauna (Diptera: Phlebotominae) of Rio Grande do Sul, Brazil and Leishmania (Viannia) infections. Mem Inst Oswaldo Cruz 94: 579-582.
Silva OS, Blazius RD, Romão PRT 2004. Flebotomíneos (Diptera: Psychodidae) coletados em galinheiro no Rio Grande do Sul, Brasil. Ent Vect 11: 283-289.

Souza NA, Andrade Coelho CA, Silva VC, Peixoto AA, Rangel EF 2005. Moonlight and blood-feeding behaviour of Lutzomyia intermedia e Lutzomyia whitmani (Diptera: Psychodidae: Phlebotominae), vectors of American cutaneous leishmaniasis in Brazil. Mem Inst Oswaldo Cruz, 100: 39-42.

Souza NA, Andrade-Coelho CA, Vilela ML, Peixoto AA, Rangel EF 2002. Seasonality of Lutzomyia intermedia e Lutzomyia whitmani (Diptera: Psychodidae: Phlebotominae), occurring sympatrically in area of leishmaniasis in the state of Rio de Janeiro, Brazil. Mem Inst Oswaldo Cruz 97: 759-765.

Souza NA, Andrade- Coelho CA, Vilela ML, Rangel EF 2001. The Phlebotominae sand fly (Diptera: Psychodidae) fauna of two Atlantic Forest reserves in the State of Rio de Janeiro, Brazil. Mem Inst Oswaldo Cruz 96: 319-324.

Teodoro U, Kühl JB, Abbas M, Dias AC 2001. Luz e aves como atrativos de flebotomíneos (Diptera, Psychodidae), no sul do Brasil. Rev Bras Entomol 45: 162-172.

Vasconcelos IA, Vasconcelos AW, Fe Filho NM, Queiroz RG, Santana EW, Bozza M, Sallenave SM, Valim C, David JR, Lopes UG 1994. The identity of Leishmania isolated from sand flies and vertebrate hosts in a major focus of cutaneous leishmaniasis in Baturite, northeastern Brazil. Am J Trop Med Hyg 50: 158-64.

Vexenat JA, Barretto AC, Cuba CC, Marsden PD 1986. Características epidemiológicas da leishmaniose americana em uma região endêmica do estado da Bahia. III. Fauna flebotomínica. Mem Inst Oswaldo Cruz 81: 293-301.

Ximenes MFFM, Bermúdez CEG, Souza MA, Freitas RA, Pearson RD, Wilson ME, Jerônimo SMB 2000. Distribution of phlebotomine sand flies (Diptera, Psychodidae) in the state of Rio Grande do Norte, Brazil. J Med Entomol 37: 167-169.

Young DG, Duncan MA 1994. Guide to the Identification and Geographic Distribution of Lutzomyia Sand Flies in the Mexico, the West Indies, Central and the South America (Diptera: Psychodidae). Mem Am Entomol Inst 54. Associated Publishers, 881pp. 
